\title{
Engineering a Business School in a Former Soviet-Era Closed City: The Case of Omsk, Siberia
}

\author{
Valeri Chukhlomin ${ }^{1} \&$ Irina Chukhlomina ${ }^{1,2}$ \\ ${ }^{1}$ Center for Distance Learning, State University of New York's Empire State College, Saratoga Springs, NY, \\ USA \\ ${ }^{2}$ Faculty of International Business, Omsk State University, Russia \\ Correspondence: Valeri Chukhlomin, CDL, SUNY Empire State College, 113 West Avenue, Saratoga Springs, \\ NY, 12866, USA. Tel: 1-518-587-2100. E-mail: valeri.chukhlomin@esc.edu
}

Received: September 27, 2012 Accepted: October 8, 2012 Online Published: November 12, 2012

doi:10.5539/ies.v6n1p26 URL: http://dx.doi.org/10.5539/ies.v6n1p26

\begin{abstract}
This article describes a modernization project undertaken by a nationally accredited Russian university located in Omsk, Siberia, and aimed at developing a new international business school. A unique feature of the project is that it was successfully implemented in a former Soviet-era closed city. Until 1991, the university hadn't had any international connections and for both local faculty and administrators the concept of international business education was a radical new idea; therefore, the project development team needed to develop the project "from scratch" in an unfavorable environment. The paper describes the process of organizational innovation where gradual modernization was intertwined with radical innovations some of which were fiercely opposed by hardliners and bureaucrats. The paper reveals the need for the project, describes the process of its development, identifies major steps in implementation, explores its design, characterizes curriculum-related problems and innovations, evaluates available resources for internationalization of the school's faculty and students, identifies roles played by various stakeholders, evaluates key success factors and provides recommendations for future research.
\end{abstract}

Keywords: emerging markets, internationalization, modernization, business education, Russia, closed city, case study, organizational innovation, organizational analytic autoethnography

\section{Introduction}

\subsection{The Unit of Analysis}

The rise of emerging markets is one of the most salient features of the world's economic and social development in the last 25-30 years (Alon \& McIntyre, 2004). The importance of emerging markets for the world economy is reflected by the fact that in 2008 their combined GDP measured at purchasing-power parity overtook the combined GDP of the developed world (The Economist, June 4, 2011). One of the largest emerging markets, Russia attracts particular attention as the world leading exporter of oil and natural gas and the $3^{\text {rd }}$ largest holder of foreign currency reserves; also, a voluminous market for consumer goods (www.roubini.com). In a matter of two decades, Russia has undertaken a remarkable transformation from a centrally-planned system to a market economy; during that time many sectors were created from scratch, such as financial infrastructure, retail trade, business education (Aslund, 1995; Goldman, 2008). The development of business education has contributed to Russia's market-oriented reforms and attracted attention of many Western scholars (Brower, 2006; Czinkota, 1997; Jacobs, 2001; Puffer, 1993; Puffer \& McCarthy, 2011). While a number of studies deal with the development of business education institutions located in Moscow and Saint-Petersburg (Judge, Miassoedov \& Naoumova, 2004; Shaw \& Ormson, 2001), significantly less is known about similar establishments in provincial Russia (Erikson, Insinga \& Kureshov, 2004; Shaw, Burakova \& Makoukha, 2000). This paper is filling the void by providing a detailed account of the development of an international business school in Omsk, a Siberian city located far away from Moscow on the border with Kazakhstan.

A unique feature of the business education project described in this paper is that it was attempted and successfully implemented in a former Soviet-era closed city. Closed cities were those that in the Soviet era were completely hidden from the outside world, foreign citizens including tourists were prohibited to visit, and the 
mentality of their inhabitants was characterized by severe isolationism (Brown, 2010; Gentile, 2004). As a result, developing an international business school in a former closed city presented a very difficult task - and as the authors argue still does. The university that hosted the described project hadn't had any international connections prior to the launch of the project; for both local faculty and administrators the concept of international business education was a radical new idea. Therefore, the project development team needed to develop the project "from scratch" in an unfavorable, sometimes hostile environment. The paper describes the process of organizational innovation where gradual modernization was intertwined with radical innovations some of which were fiercely opposed by hardliners and bureaucrats. The paper reveals the need for the project, describes the process of its development, identifies major steps in implementation, explores its design, characterizes curriculum-related problems and innovations, evaluates available resources for internationalization of the school's faculty and students, identifies roles played by various stakeholders, evaluates key success factors and provides recommendations for future research.

\subsection{The Method}

The phenomenon studied here is the internal development of the international business school at Omsk State University (Omskiy Gosudarstvenniy Universitet - OmGU) in the period that extends over 13 years - from its inception to the stage when it reached maturity. The research strategy employed is a retrospective single case study that uses organizational analytical autoethnography as the methodology (Anderson, 2006; Boyle, 2007; Denzin, 1977; Doloriert \& Sambrook, 2012; Ellis \& Bohner, 2000; Hayano, 1979; Haynes, 2011; Karra \& Phillips, 2008; Kempster \& Stewart, 2010; Parry \& Boyle, 2009). The case study strategy is chosen because not much is known about the development of international business schools in former Soviet-era closed cities; as stated by Voss, Tsikriktsis \& Frohlich (2002, p.196), "The case method lends itself to early, exploratory investigations where the variables are still unknown and the phenomenon not at all understood and exploration is needed to develop research ideas and questions". The study is retrospective as the authors do not have access to the recent data; previously, they have developed an intimate knowledge of the described project as they were the ones who initiated the project and for a long time served as the founding faculty and managers (Chukhlomin, 2007). Organizational autoethnography is chosen as a legitimate method to make sense (Boyle \& Parry, 2007) of the authors' past experience. The authors agree with Doloriert et al (2012, p. 89) that "Although some argue that narrative reconstructed from memory is not valid or rigorous, others counter-argue that any form of interpretative research is open to reconstruction. If we accept its defense, then autoethnographers should also be able to contribute by reflecting back on critical moments within their career".

Using autoethnographical work is currently becoming more established in management research, as "A reflexive use of autobiographical material provides a valuable resource for exploring, presenting and representing the self, encapsulating a personal, intuitive knowledge deriving from a knowing subject situated in a specific social context" (Haynes, 2011, p. 134). The use of autoethnography encourages researchers to adopt a hyper-reflexive stance (Hayano, 1979). In doing so researchers involve in reflection inward and observation outward (Parry and Boyle, 2009). The contribution to management learning is drawn from the observation outward by examining the inward reflections (Kempster et al, 2010). The advantage of using researchers as instruments provides depth of ethnographic immersion and richness of data (Van Maanen, 1988), but by being "too involved with the organization" (Leonard-Barton, 1990, p. 256) researchers may lose objectivity, become subject to post-rationalization and bias (Ellis et al, 2000). The problem of bias in organizational autoethnography is addressed by Boyle et al (2007, p.189): "Because organizational autoethnography is oriented so strongly toward the past, we cannot use the criterion of historical bias as a criterion for the validity of the research. In fact, we would advocate that the historical dimension is the strength of organizational autoethnography".

To make sense from their personal inward reflections and outward observations, analytical authoethographers according to Anderson (2006, p. 375) - should be "committed to an analytic research agenda focused on improving theoretical understandings of broader social phenomena". As the starting point for this study, the authors followed Miles and Huberman's (1994) suggestion that prior to engaging in qualitative research, researchers should go through construction of a conceptual framework that defines the main things that are to be studied. According to Yin (1984), case study research has been particularly good for examining the "how", "what" and "why" questions. Thus, for this study the authors proposed the following set of tentative research questions: How was the international business school at OmGU created? What were the goals that this establishment was meant to achieve and whether they were achieved? What particular resources were required, how they were obtained and what was the role of different stakeholders in this process? What were the major challenges in the process of internationalization of the school and how they were overcome? What difference did it make for the project to be conducted in a former Soviet-era closed city? 
In formulating the above questions, the authors relied on published case studies on the development of business education in other provincial cities in Russia (Erikson et al, 2004; Shaw et al, 2000), Moscow (Judge et al, 2004), Eastern Europe (Pendergast, 2009), China (Yang, 2005), Malaysia (Sohail, Daud \& Rajadurai, 2006) and South Africa (Klein, 2003); also, they examined a collection of scholarly papers on business education in emerging market economies edited by Alon and McIntyre (2004). The limitation of existing case studies dealing with the development of business education in emerging market economies is that no cases were found in the literature to describe the development of a single school for an extended period of time (more than 10 years). In addition, the literature on closed cities remains very scarce; in a way, closed cities are still a mystery. To address the tentative research questions, the authors use a biographical approach and also rely on the results of their prior research dealing with various aspects of the described case and previously published in Russia, as well as U.K. and the U.S (Chukhlomin, 2004a; 2004b; 2006; 2007; 2010a and 2010b). Providing answers to the tentative research questions, the authors draw on the existing literature dealing with broader social contexts; as the final point of their study, they come up with conclusions and recommendations that can be used in future research (Voss et al, 2002).

\subsection{Broader Social Contexts}

The immediate social contexts for this study are presented in the literature dealing with the historical developments of Siberia and Omsk (Dostoyevsky, 1965; Lincoln, 1994; Malykhin \& Chukhlomin, 1991; Naumov, 2006; Remnev, 2003; Unterberger, 1957; Zaslavskaya, 1984) and post-Soviet transitions (Aganbegyan, 1994: Alsund, 1995; Brade \& Rudolph, 2004; Melvin, 1998; Shelley, 1995), Soviet-era closed cities and their mentality (Brown, 2010; Gentile, 2004; Mikheyev, 1987), pre- and post-reformist Russian higher and secondary education issues as described in Western journals (Bain, 2003; Eklof, Holmes \& Kaplan, 2005; Elliott \& Tudge, 2007; Jarvis, Kondrashova, Efendiev \& Tukhvatullin, 2005; Kitaev, 1994; Naumova, 1998; Smolentseva, 2003; Sharygin, 2002; Zajda, 2007) and those translated from Russian (Egorshin, Abliazova \& Gus'kova, 2007; Lisauskene, 2006; Moiseeva, 2005; Prokopenko \& Baksheeva, 2008; Shabanova, 2010), the development of Western-oriented business education in Russia (Chukhlomin, 2009; 2004b; Judge et al, 2004; Puffer, 1993), transitional problems in teaching Western business concepts to Russian students (Brower, 2006; Brue \& MacPhee, 1995; Chadraba \& O'Keefe, 2007; Jacobs, 2001; Schellenberger, 1996; Shaw et al, 2000), and collaborative projects between Russian educational institutions and those from Western countries (Chukhlomin, 2010a; 2010b; 2006; 2004a; 2004b; Erikson et al, 2004; Gilbert \& Gorlenko, 1999; Judge et al, 2004; Shaw \& Ormson, 2001). The authors also draw on literature dealing with cultural differences in relation to education and training (Cardon, 2008; Gilbert, 2001; Hedgepeth \& Henrie, 2005; Hofstede, 1986; Kets de Vries, 2001; Stevens, 2000; Varner \& Varner, 1994), educational innovation in Western countries (Curtis, 2004; Van't Klooster, Van Wijk, Go \& Van Rekom, 2008;).

\subsection{The Structure of This Paper}

The main body of the paper begins with background information about Omsk as a former Soviet-era closed city followed by the needs analysis and a description of the origins of the idea of establishing an international business school there. The following section provides a brief overview of the faculty of international business at OmGU from inception to maturity. The next section is devoted to academic issues, curriculum development, faculty professional development, and pedagogical innovations. Three subsequent sections describe approaches to internationalization and provide detailed characteristics of the student population of the school. Two final sections present conclusions, derived lessons and recommendations for future research.

\section{Background}

\subsection{Omsk: From Fyodor Dostoyevsky to Jaromir Jagr}

Omsk is a big city in West Siberia, with a population exceeding one million, located on the border of Russia and Kazakhstan some two thousand miles to the east of Moscow (Melvin, 1998). In the pre-revolutionary imperial Russia Omsk played a significant role as a regional hub and the headquarters of the general-governor of Siberia (Bassin, 1991; Khodarkovsky, 2002; Lincoln, 1994; Remnev, 2003). It was in a katorga prison in Omsk where Fyodor Dostoyevsky wrote the first chapters of his famous 'Memoirs from the House of The Dead' (Dostoyevsky, 1965). In the period of the Bolshevik Revolution and the Russian Civil War, the White Russia movement attempted to make Omsk the new capital city of the whole country (Unterberger, 1957). In the Soviet period, Omsk evolved as an administrative center of a vast petrochemical, industrial and agricultural region (Naumov, 2006). In the darkness of the post-Soviet privatization (Puffer \&McCarthy, 2011; Shelley, 1995), the country's largest oil refinery plant located in Omsk was captured by Roman Abramovich, a business tycoon who also became known as the owner of 'FC Chelsea', a legendary London's soccer club (Riordan, 2007). In Omsk, 
Abramovich reportedly sponsors 'Avangard', a leading ice hockey club; for several years this team was hosting Jaromir Jagr, a famous Czech player, who joined 'Avangard' after many glorious years with 'New York Rangers' and 'Pittsburg Pinguins' (Meier, 2008).

In the Soviet era, Omsk was completely closed for foreign visitors because of many 'secret objects' [military enterprises] located there (Gentile, 2004). Even by Soviet standards, the mentality of closed cities was characterized by a severe isolationism (Brown, 2010), making them perfect examples of so called 'Soviet mindset', i.e., "a product of two generations of propaganda, command economy, institutionalized terror, and stultifying stagnation" (Gilbert, 2001, p. 5; also, Brouwer, 2006; Kets de Vries, 2001; Mikheyev, 1987). Similar to other Soviet-era higher education institutions those located in Omsk were highly specialized to produce skilled labor force for local enterprises and civil services, including industrial and agricultural engineers, medical doctors, teachers, police and military officers (Bain, 2003). OmGU was established in 1973 with a mission to prepare specialists in jurisprudence, labor and industrial economics, and also teachers, such as chemists, historians, mathematicians, philologists, physicists. Founding faculties for this new university were recruited from academically advanced cities of Irkutsk, Novosibirsk, and Tomsk. By the time of Gorbachev's perestroika (1986-91), OmGU had 3,200 full time students and a well-established doctoral program. The University developed a strong national reputation in mathematics, history and jurisprudence. In the early Boris Yelstyn's ruling period (1991-95), some of OmGU professors moved to Moscow and became known as figures of a high national caliber, including a vice-chairman of the State Duma (the lower house of the Russian Parliament), the General-Prosecutor of Russia, a member of the Supreme Court of Russia, a few members of the State Duma and the Supreme Soviet (the Senate). Like many other universities in Russia, after the collapse of the Iron Curtain OmGU suffered from a massive 'brain drain' (Naumova,1998; Smolentseva, 2003) when many leading professors of math and natural sciences chose to immigrate to Australia, Canada, Israel, Germany, South Korea, $\mathrm{UK}$, and the U.S.

\subsection{The Needs Analysis}

Currently one could hardly imagine that 20 years ago in a million city of Omsk the concept of international business education had not been introduced yet. Under the Soviet system, production and distribution of goods were centrally regulated from Moscow; entrepreneurship was a crime; possession of foreign currency was severely punishable (Brouwer, 2006; Varner \& Varner, 1994). There were only few areas where limited money-mediated operations were allowed, such as retail trade, savings, cooperatives, restaurants, public transportation. Workers in those areas were typically trained in vocational colleges; those in managerial positions studied at few specialized, mostly centrally located institutes or their local affiliate branches (Judge et al, 2004; Puffer, 1993). The overnight collapse of the Soviet communism and the advent of capitalism took the system of higher education, particularly in closed cities like Omsk, completely by surprise. In addition, with a sudden disintegration of the Soviet Union, Omsk turned to be a border city with Kazakhstan. Those unforeseen and abrupt changes resulted in an urgent need in preparing specialists that would understand how market economy operates and capable of leading the processes of its formation, including privatization, foreign trade liberalization, small business development, public services re-organization, etc. According to estimates quoted in Gilbert and Gorlenko (1999, p. 338), in 1992 there were "about 1.5 million managers...in Russia that needed training in market-oriented methods. This figure did not take into account the needs emerging for a new generation of market-oriented young managers". In Omsk alone, the demand for specialists was estimated in thousands (Chukhlomin, 1991). On the supply side, in 1991 there were fewer than 200 students studying management and economics at all OmGU departments combined, with none specializing in international business. To satisfy ever growing demand, existing educational programs needed to be radically modernized and significantly expanded; new programs were required to be created from scratch.

\subsection{Imagining a Business School}

A personal story described below supports the view that Gorbachev's perestroika was a very creative period of time when many undertakings in the field of business education were conceived and originated (Aganbegyan, 1994; Judge et al, 2004; Shaw \& Ormson, 2001). In 1988, one of the co-authors of this paper, at the time a beginning assistant professor of political economy at a local institute in Omsk, was called to participate in a mandatory, Cold War-style military training. As a trainee, he was obligated to attend a series of brain washing lectures on contemporary politics and international relations. Once, hiding from the lecturer in the last row, he was able to read a fresh newspaper, with the text of a revolutionary Gorbachev's 'On Cooperatives' law that legalized small businesses and called for entrepreneurship. This law "greatly increased the importance of training managers about the market economy, created a huge demand for such training, legalized the establishment of private business schools" (Puffer, 1993, p. 48). By the end of day, the author prepared an 
application for registration and drafted a charter of a private management development institute aimed at retraining industrial engineers and managers. By the end of the following month, the newly created institute began its operations. Successfully implemented in 1988-90, a private institute approach was very helpful for the author to understand the concept of management education and apply it in the late Soviet context (Malykhin \& Chukhlomin, 1991). At the same time, the author soon realized that in order to make a real difference, a 'brick-and-mortar' business school associated with a leading local university should be created. In 1991, the author met with the then rector [president] of OmGU Professor Valeri Viktorovich Tikhomirov and presented a proposal aimed at building an international business school. The rector of the university, a non-native of Omsk physicist and the first ever academic leader in Omsk who had been democratically elected, was actively promoting modernization and looking for innovative projects. To the author's delight, the rector enthusiastically supported the idea and soon offered him a vice-rector's position at OmGU; in 1992, a small team of young professors recruited from various Omsk universities including the other co-author of this paper was formed - and the development of the project began (Chukhlomin, 1991; 2007).

\section{A Brief History of the Faculty of International Business at OmGU}

\subsection{The Opportunity}

The only comprehensive institution of higher education in Omsk, OmGU was considered by the project team as a logical and natural setting to host a modern business school. Establishing new educational programs was permitted by the newly enacted legislation ('The Temporary Statue of Higher Education Institution', 1991), which granted Russian universities sufficient autonomy (Bain, 2003). The idea of creating an international business school was eagerly supported and shared not only by the rector and some professors at OmGU; the Governor of the Omsk Region Leonid Konstantinovich Polezhaev who had backed Boris Yelstyn and Mikhail Gorbachev during the failed 1991 coup was also in favor of the project as it was perceived as a useful measure to help globalizing the region and attracting foreign investments. Until 1991, Omsk had remained closed for foreigners; none of its higher education institutions had been allowed to maintain international connections. In the early 1992, the Governor signed a special decree to support the initiative. At the time, establishing an international business school in a provincial Russian city, particularly one that had been closed for decades, was seen as a strikingly new and groundbreaking idea that if immediately implemented might have been put Omsk only 2-3 years behind the most prestigious, privileged and well-positioned institutions of Moscow and Saint-Petersburg where first business schools had just been created (Judge et al, 2004).

\subsection{The Opposition}

But, as it soon became apparent, the proposal received not only enthusiastic supporters, but also vigorous opponents among existing faculty and administrators at OmGU. The opposition to the project was apparently rooted in two totally different worldviews. On one side, the project team intended to build a completely new curriculum following contemporary Western approaches. In particular, it presented a teaching plan where Marxian political economy, a sacred cow of the Soviet-era curriculum, was completely eliminated and a number of new disciplines were proposed, including micro- and macroeconomics, international economics, econometrics, etc. On the other side, some native OmGU faculties seemingly considered the proposal too radical; 'too American'. Also, the suggested curriculum might have been perceived by some resident faculty members as a foray into a new 'territory' that hadn't been explored at the time, but seemed potentially lucrative to be harvested in future. As a result of those internal tensions, the start of the project was delayed until late 1993; then, the new program was incepted as a small undergraduate Branch of Commerce Studies within the existing Faculty of Economics, with only 30 full time undergraduate students.

\subsection{Vision and Mission}

The mission of the new program was defined as "to promote international understanding and economic well-being of the students and faculty through strategic partnerships with prestigious international educational institutions" (www.fmb.ru/eng). Until 1997, when it celebrated its first graduation ceremony, the program remained very small. By that time, several international collaborative projects with universities from Australia, Canada, U.K and U.S were established. In 1998, a larger scale dual degree program with State University of New York (SUNY) - Empire State College was launched and supported by another decree of the Governor of the Omsk Region (The Administration of the Omsk Region, 1998). This new undertaking helped transform the Branch of Commerce Studies into an independent university school that was named FMB - Facultet Mezhdunarodnogo Biznesa [Faculty of International Business], with the goal to prepare business specialists for Russian companies entering the global market, as well as foreign companies operating within the Russian 
Federation. A six year battle for independence was finally over; the newly created school began a period of fast expansion and by 2004 its undergraduate enrollment surpassed 500 full time students (Chukhlomin, 2007).

\subsection{Milestones}

According to the initial plan adopted in 1992, FMB was intended to grow and develop into a university business school modeled on Anglo-American business schools at public universities. The milestones included the development and launch of undergraduate, graduate programs and an MBA.

\section{Academic Affairs}

\subsection{Core faculty: Inspired by Leonid Kantorovich}

In the beginning, the FMB project team's curricular approach was strongly influenced by a so called Soviet economic-mathematical school of thought, known in the West as 'The Soviet marginalist school' (Lavigne, 1997). Leonid Vitalyevich Kantorovich, a Soviet mathematician and one of the founders of this school, received the 1975 Nobel Prize in economics (with Tjalling Koopmans) for the contribution into the theory of optimal use of resources. His seminal book 'The Best Uses of Economic Resources' (1959, English translation - 1965) was recognized in the West, but severely criticized by hardliners at home. Under Khrushchev, Kantorovich, with a group of economists and mathematicians, was sent to a newly established scientific and academic center in Novosibirsk located in Siberia. There he engaged in developing theories aimed at implementing methods of linear programming in the socialist central planning. Under Kantorovich and his successors Abel Aganbegian and Valery Makarov, Novosibirsk became known for its intense use of sophisticated mathematical models in economics and an early adoption of computers; also, independent thinking (Aganbegyan, 1994; Zaslavskaya, 1984). It was perhaps the only place in the Soviet Union where students could freely and openly read contemporary Western economic journals in the library. Not surprisingly, the first teaching plan of FMB reflected the quantitative background of the founding faculty who had graduated from Novosibirsk State University; in particular, the plan included four sequential courses in calculus and other quantitative courses, such as linear algebra, linear and nonlinear programming, the theory of probabilities, and mathematical statistics.

\subsection{The Rationale behind Quantitative Methods}

Besides the founding faculty's quantitative background, there were other factors that supported a curriculum shaped towards quantitative methods. Firstly, there was an urgent need in employing forward thinking, English speaking professors, proficient in the use of information technology. At the time, the only locally available source for staffing the new program was presented by the Faculty of Mathematics at OmGU where core professors had been already "imported" from Novosibirsk. This Faculty willingly supported the project and even created a dedicated department to serve its needs. Soon, the new department engaged in developing new business-oriented courses such as business statistics, econometrics, computer information systems, and operations research. Secondly, the FMB project team wanted to attract the best student talent; at the time, such talent could only be found among graduates of local secondary schools specialized in physics and mathematics. While in the Soviet era those schools had attracted the cream of younger generation, in the early nineties there was "an overwhelming senses...that a career in pure science was no longer a viable prospect for a young Russian looking for success and security" (Gilbert \& Gorlenko, 1999, p. 330). By offering those students an opportunity to study quantitative methods in business, the FMB project team was able to secure a high level of its initial intake as reflected by the students' scores in the University's entrance examinations.

However, the orientation towards quantitative methods was found not sustainable in the long run. One reason for that was that in the nineties local companies were much more interested in graduates with broad generic business skills rather than refined specialist quantitative skills. Another reason was that in the period of transition to market economy secondary schools specializing in physics and mathematics very soon marginalized (see also Sharygin, 2002); their graduates became largely oriented towards programs in information technology and cyber security rather than business studies. Finally, business faculties, low paid in their teaching jobs (Smolentseva, 2003), were primarily interested in spending their free time on consulting in high-demand areas, such as accounting, financial services, and marketing; as a result, time consuming and research-intensive quantitative courses couldn't be sustained in FMB's teaching plans and were later largely abandoned.

\subsection{A Battle over Curricular Models: American or German?}

In a regulatory vacuum that followed the collapse of the Soviet system in 1991, innovative schools exploded and were enjoying a historic opportunity to design and teach a radically new curriculum; although, in just 4-5 years the situation dramatically changed. The infamous Russian bureaucracy resurrected under the Boris Yeltsyn's rule (Kets de Vries, 2001); as a result, by the mid-nineties the level of bureaucratic regulation significantly increased. 
For example, newly developed and nationally endorsed curricular guidelines ("National Standards of Education") were made mandatory for all accredited public and private universities. Well-intended, those guidelines soon became too detailed, influenced by interests of lobbying groups and largely inconsistent with Western practices (Baranov, 2010). Some centrally located universities were allowed to design their own curricular models; oftentimes, they did it in collaboration with Western partners (Baranov, 2010; Puffer, 1993). Unfortunately, for the FMB project team this option wasn't open; the only way to get teaching plans approved was to comply with quickly expanding regulations.

Under the Soviet-era higher education system that was originally based on the German model of higher learning undergraduate students studied 5-6 years full time to get a qualification of Specialist, sometimes translated into English as 'Diploma of Completion' (Zajda, 2007, p. 22). In some English-speaking countries a Specialist Degree was seen as an equivalent to a Bachelor's degree, in others - a combined Bachelor's and Master's degree. One of the major problems with the Soviet-era specialist degree model was that it was intended to prepare narrow-focused specialists for particular professions and even types of jobs in the planned economy; at any given term students were required to take at least 9-10 subjects. As a result, students were overloaded with 'sage-on-the stage' type lectures; rote memorization was necessary to succeed in multiple oral examinations (see also, Kets de Vries, 2001; Schellenberger, 1996; Zajda, 2007). To depart from the Soviet-era model, in 1992 the first post-Soviet and thus far the most reformist Russian government attempted to introduce an Anglo-American two stage Bachelor-Master system of qualifications (Baranov, 2010; Kitaev, 1994; Smolentseva, 2003). The development of curriculum guidelines for newly introduced Bachelor's degrees was sponsored by the Open Society Institute; those guidelines were largely synchronized with contemporary Western approaches and were not that parochial as specialist degrees. The FMB project team chose a Bachelor of Commerce model in anticipation that in a matter of few years the reformist government would eliminate specialists' degrees, as it had declared. In reality, it was the reformist government that was soon eliminated. During next several years graduates of 4-year programs were treated as incomplete specialists (Smolentseva, ibid); for example, in Omsk they were rejected entry to postgraduate Aspirantura $(\mathrm{PhD})$ programs in the OmGU Faculty of Economics. As a result, in 1998 the FMB project team had to convert the most of its undergraduate teaching into a more traditional, 5-year specialist model. It was only in 2010 when a new generation of national standards of education influenced by the Bologna process was enacted that re-introduced the Bachelor-Master model (Baranov, 2010; Chukhlomin, 2011).

\subsection{Selecting Concentrations: Economics and Marketing}

To lay a solid foundation for specialist courses, the FMB project team engaged in developing a series of courses in contemporary economics. According to Shaw et al (2000, p.30), "developing competitive programs in economics and market-oriented courses [was]...challenging because of the lack of qualified faculty. Most Russian teachers grew up with, and were trained in, Marxian economics and authoritarian approaches to teaching that". Fortunately, having an economic-mathematical background was very helpful for the FMB founding faculty, because the Kantorovichean model of the optimal use of economic resources is in reality a linear version of the Walrasian general equilibrium model which is in turn one of the theoretical foundations of modern economics (McKenzie, 2002). In 1991, one of the authors of this paper designed a series of courses in microeconomics at introductory and advanced levels followed by courses in international economics, economic growth and development, and theories of economic thought. In 1992, he was followed by the other co-author who started to teach modern macroeconomics and monetary economics (Chukhlomina, 2002). The development of these courses was largely influenced by earlier works by Stanislav Menshikov, policy papers by Yegor Gaidar and translated in the Soviet period textbooks, in particular, a macroeconomic text by a French economist Lionel Stoleru. Very soon, a number of new and very useful translations appeared, including texts by McConnell and Brue (Brue \& MacPhee, 1995), Pindyck and Rubenfield, and Gregory Mankiw. In 1992-93, the development of new courses in the school was partly supported by grants from the Government of Omsk Region and the Open Society Institute.

Marketing was chosen by the FMB project team as the first concentration area to develop for a number of reasons. First of all, as an academic discipline, marketing connects very well with microeconomics. Second of all, quantitative courses already built into the curriculum were supposed to be very helpful for students learning marketing research methods and techniques. Yet another reason was that Philip Kotler's seminal works on marketing had already been translated into Russian which provided faculty with much needed guidance (Jacobs, 2001). Finally, developing courses in export marketing and international trade was seen by the FMB project team as a necessary step to fulfill the mission of the school. 


\subsection{Faculty Development: Field Work and Academic Inbreeding}

Developing marketing concentration in a former closed Siberian city in the early nineties presented many challenges [also, see Chadraba \& O'Keefe, 2007]. At the time, marketing was usually seen in Russia as a selling technique; it took several years for local enterprises to understand and start using marketing philosophy (Chukhlomina, 2003). It was found extremely difficult to find professors who could teach contemporary marketing. Unlike economics, teaching courses in marketing required from faculty having practical experience. Those academics that had quickly learned the essentials of marketing approach and developed necessary skills usually preferred to work full time for local businesses. Those that stayed in academia and tried to base their teaching upon regurgitation of concepts and facts derived from translated textbooks were not seen by students as experts. To develop and retain faculty and provide faculty and students with practical experience and internships, the FMB project team established a center for marketing research. The center's task was to arrange contacts with local firms and coordinate internships and projects; it also became a corporate member of the Russian Marketing Association. Over time, the center was able to develop a broad network of contacts with local enterprises; many students found employment as a result of their final projects. Another positive outcome of the center's work was that by doing field projects and supervising students' internships and final projects marketing faculty were able to significantly increase their research activities. Initially, teaching, program development and consultancy were the three top priorities for the FMB faculty; at the time, it was quite common for Russian academics and is consistent with observations made by Jarvis et al (2005). Since the mid-nineties, the intensity of research activities of the school has significantly increased. For example, a series of working papers was established, followed by a number of articles published by the school's faculties in national journals, textbooks and monographs.

Overall, it took almost 10 years for the marketing concentration to fully fledge; during that time, some students graduated and joined the school. In 2003, the first home grown PhD dissertation in Marketing was defended. While academic inbreeding [hiring own graduates] is not considered the best practice by Western standards (Horta, Veloso \& Grediaga, 2010), for the FMB project team this approach seemed to be the only possible solution to staff the school with well-trained and dedicated new faculty members.

\subsection{Educational Innovation: From Wrigley Chewing Gum to Competency-based Approach}

Although developing a new curriculum presented formidable challenges, it also allowed the FMB project team to explore some radically new ideas, such as competency-based approach. Competencies came into the picture when the project team was contemplating about a possible curricular approach that could provide graduates with a set of "winning" employability skills. Inspiration came from reading a job advertising message by a chewing gum manufacturer 'Wrigley'. In the early nineties, the company was developing a network of sales representatives in Russia and published a series of advertisements in the Russian national media. By Russian standards, those messages looked very unusually emphasizing a set of required skills that were not typically taught at Russian universities; remarkably, those job descriptions were all written in English. The required set of skills included English language, oral and written communication skills, teamwork, project management, and time management. The FMB project team decided to fine tune the school's curriculum in a way that would allow graduates to be equipped with graduate outcomes that were apparently highly valued by recruiters working for international companies in Russia; at the time, this was a very innovative approach. In 1993-94, the team received funding from the Ministry of Education of the Russian Federation to explore the idea and find ways to waive a competency-based approach into the school's teaching plan. The idea was not only to identify and build into the school's curriculum the required set of graduate outcomes, but also to develop a set of standards and benchmarks to measure levels of competencies achieved by students (Chukhlomin, 2007). Internally, this approach was referred to as 'Standarty navykov' [standards of skills]; it corresponds well with employability skills as defined by Curtis (2004).

Thinking retrospectively, the development of a competency-based approach was perhaps the most important pedagogical innovation of the school in the nineties. A list of required competencies was developed; each term students were required to conduct a specific competency-oriented term project. Required competencies included the following skills: academic writing skills (term 1); business planning skills (term 2); economic analysis and reporting skills (term 3); marketing research skills and teamwork (term 4); English language communication skills (terms 5-6). Each of the term projects was conducted in a 4-5 months period and was supported by 2-3 academic courses; public defense of completed projects was required at the end of each term. In the final year, students were required to conduct two comprehensive projects, including an individual marketing research project and internship (term 7) and a final research thesis (term 8). As a result of this innovation and its successful implementation, FMB very quickly gained high reputation on the local job market; it was (and 
perhaps stills is) common to see a job advertising in local media saying that a marketing job was available where 'an FMB graduate is preferred'.

\section{Internationalization: Phase One}

\subsection{Looking for Partners: A CIBER in Siberia?}

While international business was specifically targeted by the FMB project team as the mostly desired academic major to develop, in the beginning it was not quite clear how to approach it. The university's administration denied a request made by the FMB project team to use a standardized test of English as a sole foreign language entrance examination; instead, the university's entrance examinations were conducted in three foreign languages (English, German and French). As a result, students enrolled in the school spoke different second languages. Another problem was caused by the fact that Omsk was a closed city for such a long time; initially, there were no connections with foreign universities and no access to potential seed grants. Unlike Moscow and Saint-Petersburg, finding grants for developing joint degree programs with Western universities was found to be very difficult in Omsk. However, the FMB project team managed to develop several small scale projects with international counterparts. For example, for a number of years, each summer a team of Canadian instructors from the Richard Ivey School of Business at the University of Western Ontario travelled to Omsk to teach management courses for 3 weeks (www.leaderproject.com). Under an agreement with an American private college from North Carolina, each year 2-3 Omsk students with the highest TOEFL score were able to transfer to the partner college to complete a Bachelor's degree where tuition fees and accommodation costs were fully paid by the American partner. There were also faculty exchanges with the Graduate College of Management at Southern Cross University in Australia and Wolverhampton University in the UK. All those agreements resulted in a much better understanding of the current curriculum models and teaching methods used in the West. Particularly important was a visit by one of the authors of this paper to the U.S. in 1997 sponsored by the former United States Information Agency (USIA). This was a unique opportunity to get a very broad exposure to American business education; in particular, the author got familiar with the work of so called CIBERs (centers for business education and research) created by many U.S. universities (www.cybernet.org). As a result, a center for business education and research (CIBER) at OmSU was established; later, it transformed into the Russian-American Branch of the Department of World Economy.

\subsection{Teaching in English and Fighting Bureaucracies}

In 1999, FMB was licensed (and then accredited) by the Ministry of Education to provide teaching and award academic qualifications in World Economy. At the time, the philosophy of the Russian Specialist in World Economy degree was that graduates were supposed to become generalists with some knowledge of a foreign language, world cultures, economy and geography. Obviously, this was an outdated approach; it might have been valid some 40-50 years ago when Soviet-era state-owned enterprises had been working on government-mediated contracts in China, India and Egypt. A specialist in World Economy could be someone who had only attended courses in Russian accounting, Russian business law and spoke no English at all! For this new program the FMB project team defined its own principles of curriculum design in the following way. First of all, a program in World Economy must be conducted fully or substantially in English. Then, the body of knowledge and skills that graduates of the program are supposed to obtain must be consistent with contemporary (=Western) approaches. Lastly, students and professors should be able to easily move between similar programs conducted in different countries (Chukhlomin, 2007).

Because this innovative approach was far ahead of the then government-approved guidelines, it needed to be executed with great caution. Even more, a straightforward application of those principles wasn't possible, but there were ways around the bureaucratic system. To begin with, in order to comply with the University's requirements, entrance examinations in mathematics, Russian language and three foreign languages were conducted for the whole applicant body of the school regardless of their preferred major. After that, for those wishing to enroll in World Economy, an intensive study of English was offered during Year 1 followed by an additional examination executed internally by FMB. By doing so, the school filtered the students and selected only those who were well prepared to studying in English. The next problem was how to legitimize teaching in English. At the time, all university teaching was provided in Russian as the official language of education in the country; English as a language of instruction was permitted if only conducted by the OmGU Department of English Language and Literature. But this department didn't have the expertise to teach subject matter courses in World Economy! A solution that was found by the FMB project team was to create its own English language department within the school and to get it approved by the University; politically, this was a very difficult and risky decision that turned away the OmGU Department of English Language and Literature and increased 
opposition to the project within the University. But the goal was achieved; as a result, teaching of subject matter courses in English was made possible.

\subsection{The Role of CEP and the Open Society Institute}

The next step was to find professors capable of teaching subject matter courses in English. Unlike Moscow and Saint-Petersburg, there were no visiting faculties, expatriates, or local English speaking professors in Omsk. The problem was solved with the help from the Civic Education Project (CEP), another initiative sponsored by the Open Society Institute (civiceducationproject.org). Through CEP, several dedicated professors, mostly native English speakers, were brought to Omsk for 5-10 months each. Mostly teachers of history and other non-business courses, those professors were very instrumental in developing and teaching courses where students were required to develop supplementary competencies in English academic writing, communication skills, and research skills. As far as business courses were concerned, several solutions were found. First of all, many videotaped lectures in accounting, finance, marketing, management were purchased in the US. Second of all, there were incidentally visiting guest lecturers from English-speaking countries. Thirdly, some courses were made bilingual and conducted in Russian, accompanied by teaching materials in English. Finally, under new agreements with international universities, some courses were delivered by partner universities either online, or in a blended format. Working with partner universities was found to be critically important for the modernization of the old Soviet-era specialist in World Economy model and is described in the following sections.

\subsection{World Economy: A Program for Those Who Leave}

Since its inception, the new program in World Economy became extremely popular among students and attracted many full fee paying students. Since 2004, in addition to 30-40 new full time undergraduate students in marketing, each year the school has been able to enroll 50-70 new full time students in World Economy; in 2009, it started a Master's program in World Economy. For students that were interested in studying and eventually moving abroad, the new program opened multiple opportunities. But as it turned out local employment prospects for graduates of this program were not that bright as for marketing graduates. The economic development of the Omsk Region hasn't so far attracted significant international investments; as a result, many graduates elected to relocate to more vibrant and globalized cities, such as Moscow, Novosibirsk, Saint-Petersburg and Yekaterinburg.

\subsection{A Project with SUNY: The Flagship Double Degree Program for the School}

When looking for strategic partners, the FMB project team considered the State University of New York (SUNY) a highly desirable partner for the following reasons. Firstly, its brand name was perceived to be of high value. Being a "State University" in Russia was found to be synonymous with being a high quality institution of higher education; "New York" is universally seen as a symbol of international business. Secondly, SUNY is well known in Russia because of its partnerships with the most prestigious national universities of Moscow and Saint Petersburg (Chukhlomin, 2010b). Empire State College, a SUNY campus headquartered in Saratoga Springs, NY, was specifically targeted by the FMB project team as the only SUNY college that was offering two highly attractive options: 96 credits transfer and distance learning. The partnership was arranged with the help of the USIA and the American Consulate in Yekaterinburg. After an initial mutual screening and an exchange of visits, a Memorandum of Agreement was signed in Omsk in June 1998, with the Governor of Omsk Region as the witness. According to the initial plan, every year ten junior level students from FMB were supposed to begin their studies at SUNY Empire State College (SUNY ESC) through international distance learning (IDL). To get a SUNY Bachelor of Science degree in Business, Management and Economics, they were supposed to transfer 96 credits taken in Omsk towards the degree, including 5-6 advanced level courses; the remaining 32 credits were required to be taken directly from SUNY ESC through IDL.

\subsection{Modernization through Internationalization}

After the first four years of the SUNY project, only one student from Omsk was able to complete all required courses and graduate from SUNY ESC through IDL. Several dozen students took only a few IDL courses and then discontinued. To find out the root causes and to learn more about their learning experiences, the FMB project team was constantly interviewing all participating students. Many of them reported that print based courses were not engaging and it was hard to study without personal contact with the teacher; students were not familiar with many concepts used in advanced level IDL courses. To better prepare students for the American college experience, the FMB project team decided to implement significant curricular changes. In the process of modernization, all introductory business courses in the school were revised to incorporate concepts and terminology commonly used in the U.S. These updated courses became an integral part of the school curriculum in World Economy; several new elective courses were developed and added to the Omsk curriculum, including 
American Financial Accounting, American History, English Academic Writing, Business Research Methods, and Business Communications. Overall, those curricular innovations were perhaps the most important result of the entire collaboration with SUNY because the change enabled the whole student population of the school to benefit - rather than only a relatively small group of the SUNY program participants.

\subsection{A Successful Design}

The initial program design was also significantly changed. Instead of offering SUNY ESC courses in a fully distance mode, it was decided to switch to a blended learning model. A SUNY community college, located in Broome County, New York, expressed its interest in taking over the IDL part and re-designing it into a blended format. Since 2005, a team of SUNY Broome professors has annually traveled to Siberia to conduct face-to-face classes. To get a SUNY Associate Degree, Omsk students are required to take only five courses from Broome on top of the home degree, at a lower tuition fee rate. Graduates of this program are provided with an option to complete a SUNY Bachelor's degree either entirely online through IDL, or to travel to Prague, Czech Republic, to study face-to-face at the SUNY ESC's unit hosted by University of New York Prague (UNYP). The results of the above changes proved to be very positive. Since 2004, every year the SUNY ESC's Prague Unit has been welcoming 10-12 new students from Omsk coming to Prague to complete their SUNY Bachelor's degree in a face-to-face format.

\section{Students}

\subsection{The Target Audience for International Programs}

Initially, the FMB project team was targeting local students that were interested in studying (and eventually moving) abroad (internally referred to as 'cosmopolites'). Rather small, this category of students was very visible, proficient in English and academically advanced. Usually, those students enthusiastically participated in sponsored events, such as pre-paid collaborative courses. At the same time, they were actively looking for scholarships from Western universities and were often reluctant to participate in collaborative tuition fee-based programs.

It was eventually discovered that the most promising target audience for fee-based collaborative projects was represented by a different category of students. Those students were significantly more numerous, initially less proficient in English and generally more oriented towards finding jobs in Moscow and Saint-Petersburg rather than moving abroad ('domestic migrants'). In Russia, moving to Moscow or Saint-Petersburg is a highly desirable goal for many graduates, as job prospects and salaries for qualified professionals in the capital cities are significantly higher than in the rest of Russia and Eastern Europe (Brade \& Rudolph, 2004). A combination of the Omsk degree, a SUNY degree, and a study abroad experience was found to be a highly effective method for domestic migrants to become competitive in the most lucrative job market in the country. For this category of students, the demand for American education was uncovered in the process of the project development. Also, there was another (and the largest) category of students that were attracted to FMB because of its international flavor, but were found to be interested mostly in its domestic programs, such as World Economy or Marketing, with no active interest in collaborative activities whatsoever ('homebodies'). It took a while for the FMB project team to realize that 'homebodies' could also be engaged in fee-based international activities (this is addressed in the following section).

From the very beginning, the FMB project team made it clear that the Russian-American program was intended to be tuition fee-based and that no scholarships would be available for participants. This approach was different from many other cases in Russia where seed grants were initially offered for participants to cover tuition fees. While it is rare for a seed grant-based project to survive when the seed money is gone (Gilbert \& Gorlenko, 1999), the down-to-earth tuition fee based approach implemented in Omsk proved to be more sustainable in the long run.

\subsection{How to Teach American Courses in Siberia}

While working on the collaborative project with SUNY, it was found that Omsk students were using different learning strategies than American students; they had a different set of skills than American professors would typically expect them to have (Chukhlomin, 2010a). This corresponds with observations made by Hedgepeth and Henrie (2005; see also Chadraba \& O'Keefe, 2007; Czinkota, 1997). Participating Omsk students were not familiar with the American context and did not have enough knowledge to effectively participate in ongoing conversations and discussions with American students that were based on American experience and recent events in the U.S. The distance learning pedagogy used by SUNY professors and instructional designers was based on the American classroom practice and attuned to a low context, text-based, student-centered culture, 
while Russian culture is high context and teacher-centered (Cardon, 2008; Chukhlomin \& Deshpande, 2011; Hofstede, 1986; Stevens, 2000). In addition, Omsk students were not familiar with academic policies that were used in the American institutions. To mitigate cross-cultural barriers, the FMB project team created a simulated learning environment that was referred to as a 'laboratory of culture shock' (Chukhlomin, 2010b). Two rooms in Omsk were decorated as a 'New York office', with English-speaking personnel, cable television and other media, and books. Here students were taking classes with American professors, with the requirement to conduct classes "as in the U.S". With the addition of blended learning and an optional study abroad component, the above mentioned teaching and learning problems were mitigated.

\subsection{Educational Technology and Knowledge Transfer}

For the FMB project team, the SUNY program was tremendously helpful in terms of educational technology transfer and professional development. For example, FMB was the first school in Omsk to create a website (www.fmb.ru), a Web portal, award-winning thematic websites on international business and economics for Russian-speaking economists; eventually, FMB developed its own international distance learning program to support its students studying abroad. International education marketing was another capability that was developed by the FMB project team under the direct influence of SUNY and its partner institutions in Europe. It was found that original marketing materials provided by American institutions were not very useful for local marketing, as they had been prepared by SUNY colleges for an upstate New York audience. Inspired by the example of New York College in Greece (www.nyc.gr), the FMB project team created a synthetic brand identity for the SUNY program in Siberia, with an emphasis on "New York" and "International Business".

\section{Internationalization: Phase Two}

\subsection{Beyond Double Degree Programs}

In 1999, the FMB project team made a decision to engage in an international partnership aimed at delivering some of the FMB courses abroad (Chukhlomin, 2004a; 2006). An ability to remotely deliver courses in a developed country was perceived by the team as a critically important component of globalization of the school; also, as demonstrated by researchers, study abroad had a wide variety of benefits for participating students (Sachau et al, 2010). By surveying students and their parents, the team discovered that there was a room for a new undergraduate degree program where Omsk students would travel to a developed country as part of their home degree program. Before this discovery was made, the FMB philosophy was essentially built around the concept of double (dual) degrees as defined by Knight (2010). According to this philosophy, obtaining a brand name foreign university degree was quintessential for students wishing to relocate either to a developed country ('cosmopolites'), or Moscow and Saint-Petersburg ('domestic migrants'). Then, it was found that a sizeable proportion of students identified earlier as 'homebodies' expressed an interest in participating in a hypothetical program that could be organized and managed by the school in another country. For those students, earning a foreign tertiary qualification was found not to be critically important; what really mattered for them (and their parents) was an opportunity for global exposure in a protected environment. This sub-set of students was defined as potential 'educational tourists'. A characteristic feature of this sub-set of students was that their initial level of English was relatively poor; not surprisingly, they usually didn't attend international education fairs and promotional events. As many potential 'educational tourists' travelled abroad with their parents during winter and summer breaks, they were used to international travel and their families were able to afford it. From the FMB project team's perspective, it seemed logical and enticing to develop a special academic program serving the needs of 'educational tourists'. According to the literature, "an important objective of educational travel programs is to teach students how to bridge cultural distance" (Van't Klooster et al, 2008, p. 690; also, Sachau et al, 2009). In international services marketing literature the type of internationalization strategy chosen by the FMB project team is known as 'client-following' (Gronroos, 1999).

\subsection{Why Australia}

To develop a transnational project (GATE 1999), several alternative destinations were examined, including Australia, Canada, Czech Republic, Finland, Greece, Netherlands, New Zealand, U.K. and the U.S. A list of considered factors included the following: a) a developed, preferably English speaking country; b) favorable student visa regulations; c) moderate tuition and related fees; d) moderate travel costs; e) high standards of living, friendliness, available part time jobs, etc. A relatively remote destination, Australia was chosen for a number of reasons, including well-developed infrastructure for international students; a relatively cheap - at the time Australian dollar, a high standard of living; a great reputation for recreational activities and tourism; a relative abundance of part time jobs available for international students; convenient locations of international colleges in downtown Sydney (see also Harman, 2004). In addition, in 1994-96 FMB had conducted a joint faculty 
development and training project with Southern Cross University sponsored by AusAid; this project was very helpful for collecting necessary information about Australia and developing useful connections.

\subsection{Developing a Transnational Project}

In 2000, a brand new, full-fee based, 4-year Bachelor of Economics program, with a concentration in International Business, was designed for the Australian project. It was anticipated that Omsk students would begin their full time studies at home, then travel to Australia for 1-2 or even 3-4 semesters and finally return back home for the rest of their studies. To get and maintain an international student visa in Australia, the students were required to enroll in a local vocational college in Sydney and take Academic English and/or vocational courses in international business. While in Australia, the students were required to maintain full time enrollment at the home institution as well; to do so, they needed to attend introductory lectures and workshops in Omsk before departure, then continue their studies in a distance learning format and, finally, to pass examinations upon return. The advantage of partnering with Australian colleges representing the system of vocational education and training (VET) was that it provided the most economical way of obtaining international student visas; as students were required to pay tuition fees in both institutions, the total cost of participation in the program needed to be restrained. Other advantages included convenient location (usually, downtown Sydney), high quality English language programs, well equipped computer classes, multicultural student population, standardized curricula articulated with Australian universities (also, see Harris et al, 2006).

To support the Australian program, two specialized units were created; one office, called the Australian Education Center (AEC), was charged with student visa applications and marketing; another office, called the Sydney Branch of the Department of World Economy, was responsible for curricular issues, distance learning, academic support and relations with Australian educational institutions. Building on experience gained in the SUNY program, the FMB project team prepared to deliver courses transnationally. A regulatory framework for distance education in Russia was already put in place (Moiseeva, 2005; Prokopenko \& Baksheeva, 2008). When in Australia, the students were studying face-to-face at a partner vocational college and remotely at the home institution where contacts with professors were conducted through email. In addition, two private vocational colleges located in Sydney agreed to support the program by employing Russian-speaking managers to work with Omsk students and coordinate their studies in Australia. Also, partner colleges provided the students with access to computers and the Internet to conduct their distance learning studies; provided rooms for Omsk representatives to meet with the students; stored textbooks and other teaching materials received from Omsk. Periodically, usually once a year, a small team of Russian professors travelled to Australia to conduct face-to-face sessions.

\subsection{The Results of the Australian Project}

Overall, in the period of 1999-2005 about 50 students from Omsk participated in the Australian program; approximately, $50 \%$ returned back home and another 50\% remained in Australia longer that was required by the program and some chose to stay permanently (Chukhlomin, Chukhlomina and Thomas, 2012). Many who decided to stay permanently later completed Master's and MBA programs in Australian universities, such as Macquarie University, the University of Sydney, the University of New South Wales, Victoria University of Technology, Swinburne University of Technology, and Central Queensland University. In the eyes of students that were primarily interested in moving abroad ('cosmopolites'), participation in the program was seen as a safe way to familiarize with Australia and select an Australian university for transfer. As far as 'educational tourists' were concerned, participation in the program was typically seen by them and their families as a safe and tested way to get global exposure, learn English and communications skills in a protected environment. Oftentimes, the decision to participate in the project was made for a student by her parents who would also select Australia as a holiday destination for the entire family for several consecutive seasons. It was not rare for Omsk parents to consider Australia as a safe destination for a teenaged student to begin living independently, without the stress and dangers of living in a big city in Russia. Interestingly, patterns of behavior demonstrated in Omsk by families of 'educational tourists' and discovered by the FMB project team were very similar to those of families in South-East Asia described by Pimpa (2003) in a research paper on family influence on Thai's students' choice of international education programs.

\subsection{Associated Problems}

Successfully implemented, the Australian program was a fairly unique experiment for a Siberian university and, as such, it served as an impressive demonstration of the FMB project team's ability to conduct international programs and provide support for its students in a remote country. Importantly, FMB was able to collect tuition fees even when the students were abroad; this made the program financially self-sufficient. On the organizational 
side, problems related to coordination of the program including curricular planning, international collaboration, and a very sophisticated logistics, were initially perceived as the most difficult to solve. But, as it turned out, problems associated with external and internal environments proved to be much more difficult to deal with. External problems included currency fluctuations, changes in student visa policies and migration regulations, and the instability of private colleges in Australia (Ross, 2011). Internal organizational problems that eventually caused the program to close included over-regulation, a 'cash cow' approach, and a lack of support from the home university administration (Chukhlomin, 2006).

\section{Conclusions and Derived Lessons}

\subsection{Main Results}

Starting from scratch, it took the FMB project team a little more than 10 years to build a modern, highly successful educational program. As a result of its continuing innovation and strategic collaborations, FMB has grown from 30 to 500 full-time undergraduate students and has recently started its first Master's program. Some of its graduates have successfully completed high profile graduate schools, such as University of Chicago Business School, Columbia University Business School, Carnegie Mellon University, DePaul University, Florida International University, Michigan University, The University of Sydney, Macquarie University Graduate Business School, as well as many other leading international business schools. Many graduates are employed by leading American, Australian, British, German, French, Russian and other international companies. FMB has become an undisputed leader in the field of international and marketing education in West Siberia and North Kazakhstan.

\subsection{Resources and Key Success Factors}

To achieve the dream, the FMB project team utilized many locally available resources that included those provided by Omsk State University and the Ministry of Education of the Russian Federation; small grants received from the Open Society Institute, the Ministry of Education of the Russian Federation, the USIA and the Government of Omsk Region; American faculty members paid by the Civic Education Project; the university's state-of-the-art Internet Center supported by the Open Society Institute. While invaluable, those (or comparable) resources were not Omsk-specific and could be mobilized in any large Siberian city. Outside Omsk, there are other examples of successful international business programs in Siberia, such as Russian-American schools in Irkutsk, Krasnoyarsk and Vladivostok (Erickson et al, 2004). By visiting those schools and meeting with their founding faculty, the co-authors did find many striking similarities. Based on own observations, and also frequent private conversations with managers of successful (and also not so successful) educational programs in Siberia, the co-authors derived a conclusion that the most important factors that contributed to the ultimate success of the project were a) visionary organizational leadership and b) a highly coordinated teamwork; both factors can be combined and described as 'transformational leadership' (Elenkov, 2002). Other key success factors included: c) support from the top university administrator and the top regional administrator; d) exposure to Western practices and knowledge transfer.

\subsection{Environmental Factors}

Environmental variables, such as the level of economic activity in the region, disposable income, entrepreneurial climate, foreign investments, academic traditions and culture, also played a role. In Omsk, as a former closed city, the environment was found to be not-so-friendly; resources were difficult to mobilize; some resources like seed grants were practically inaccessible; the amount of time and effort needed to overcome multiple bureaucratic obstacles was enormous. The implementation of many vital initiatives was significantly delayed and some initial plans the FMB project team was not able to realize as it was intended; most notably, the launch of its MBA program was postponed as the local job market wasn't (and perhaps still isn't) ready.

\subsection{Internal Organizational Factors}

Despite (or, because of) the undeniable success achieved by the FMB project team, the bureaucratic resistance to innovation and change within the university didn't lessen over time making every new step for the team more difficult to take. The administrative pressure particularly increased in 2003-2004; this coincided with the overall trend to a more strict state control and greater authoritarianism in Russia (Evans, 2011). As a result of escalated tensions, in the late 2004 the founding faculty had no other choice but to resign. This outcome supports the view that the Soviet-era view of independent thinkers as anti-socials, troublemakers, hooligans - enemies of the people - still holds force and will need time to be changed' (Kets de Vries, 2001, p. 619). Luckily, the school has survived and is continuing to beat the odds; but that's another story. 


\section{Limitations and Recommendations for Future Research}

The current case study is a rare example of a retrospective analysis of the development of an international business education project in a former Soviet-era closed city and covers a significant period of time (13 years) from inception of the project to maturity. It is based on an in-depth knowledge of the authors who both served as the initiators of the project, founding faculty and managers; as such, it has provided a very rich in detail description of the project answering the above mentioned "how", "what" and "why" questions.

However, in terms of generalizability the study has three significant limitations. One limitation is that it describes a single case. Another limitation is that it is based on the reconstruction of past events by participants; as such, it is subjective. Yet another limitation is that the authors didn't put forward any prior theory to test. To make sense of the field work conducted by the authors more research is needed. One of the directions for future research is to use a longitudinal study for the same unit of analysis. As suggested by Leonard-Barton (1990, p. 248), "Retrospective studies offer the opportunity to identify patterns indicative of dynamic processes and the longitudinal study provides a close-up view of those patterns as they evolve over time". Another direction is to replicate the same combination of retrospective and longitudinal studies across multiple cases; this approach will have a potential for developing a grounded theory (Glazer \& Strauss, 1967) to explain the process of developing new international education establishments in former Soviet-era closed cities or - more broadly - the process of developing Western-oriented organizational innovations in organizations located in former communist countries. Potential sites for suggested case studies can be found in other former Soviet-era closed cities in Russia (or other post-Soviet countries), other provincial cities and capital cities in former communist countries. In addition to educational institutions, organizational innovations can also be found and tracked in organizations representing other sectors, such as financial, retail, information technology, etc. To hone research questions and hypotheses, the present study can provide with some constructive ideas, for example, in relation to key success factors, the role of transformational leadership, the role of technology transfer, various environmental factors, etc.

While writing this autoethnography, the authors put aside some observations and considerations that didn't fit well into the cohesive narrative, but might have been important if explored in a broader social context. Those observations may be relevant for conducting studies across many organizational settings to form "a big picture" of the post-Soviet social change (Evans, 2011). Below is a list of those observations and considerations:

- The development of an international business school in a former Soviet-era closed city is just an example of a pro-Western organizational innovation in an environment that can be considered as anti-Western; in the early nineties, many pro-Western innovations were introduced in organizations representing various sectors of the Russian economy and society (financial institutions, retail trade, mass media, etc.); for quite some time, those "new" units co-existed with "old" ones in an unfriendly and sometimes hostile environment. One may suggest that the phenomenon studied in this paper can be seen as part of a much broader social process of the post-Communist transformation; as such, it is likely to have common characteristics with "new" units in other areas.

- Most likely that one common feature shared by "New" units across all sectors is that they were developed by people that can be characterized as social entrepreneurs and visionary leaders. One may suggest that those individuals shared some common characteristics, values and attitudes (such as risk taking, missionary leadership, creativity, perseverance, concern for society, collaboration, and open-mindedness).

- It is likely that abrupt political and social changes, such as the emergence of the "Petrostate" (Goldman, 2008), adversely affected the development of "new" units and on some occasions pre-determined the fate of their founders and developers. One may suggest that at the turn of the century many "new" units established in Russia in the nineties were experiencing serious turbulence with varied outcomes; the authors have anecdotal evidence from their personal experience, as well as shared with them other people's stories, and call for more biographical research.

\section{Acknowledgements}

The authors would like to take this opportunity to devote this article to the memory of their teachers, Olga Konstantinovna Mikhailova and Yuri Alexeevich Chizhov. In addition to those mentioned in the text, several people provided significant assistance in launching and developing the project including Vyacheslav Vasilyevich Malykhin, Leonid Andreevich Yelovikov, Vyacheslav Isaakovich Vershinin, Valentin Gennadievich Ryzhikh and many others. Besides the authors of the paper, Yuri Petrovich Dous and Irina Gennadievna Knyazeva were among the 'magnificent four' founding faculty members. The success of international programs was possible because of the invaluable contribution provided by professors Kenneth Abrams, Richard Bonnabeau and Philip A. Neck. Overall, the project wouldn't have succeeded without dedication of the faculty, support staff, 
wonderful students and their parents, and also a very important help provided by the Open Society Institute and its affiliates, the Government of the Omsk Region, the USIA and the American Consulate in Yekaterinburg, and visiting professors.

\section{References}

Administratsiya Omskoy Oblasti [The Administration of the Omsk Region]. (1998). O podderzhke Rossiysko-Amerikanskogo Proekta s Uchastiyem Omskogo Gosudarstvennogo Universiteta. Postanovleniye Glavy Administratsyy [On the support of a Russian-American Project with participation of Omsk State University. A Decree of the Governor of the Omsk Region]. Retrieved from http:// www.lawru.info/base94/part3/d94ru3209.htm

Aganbegyan, A. (1994). Economic challenges of perestroika. London, England: Macmillan Press.

Alon, I., \& McIntyre, J. R. (Eds.). (2004). Business education and emerging market economies: perspectives and best practices. Boston, MA: Kluwer Academic Publishing.

Anderson, L. (2006). Analytic ethnography. Journal of Contemporary Ethnography, 35(4), 373-395. $\mathrm{http}: / / \mathrm{dx}$.doi.org/10.1177/0891241605280449

Aslund, A. (1995). How Russia became a market economy. Washington, D.C.: Brookings.

Bain, O. B. (2003). University autonomy in the Russian Federation since perestroika. London, England: Routledge.

Baranov, I. N. (2010). Standarty tret'ego pokoleniya i konkurentsiya v biznes-obrazovanii [Third generation national standards and competition in business education]. Vestnik S.-Petersburg University, 8(1), 166-183.

Bassin, M. (1991). Inventing Siberia: Visions of the Russian East in the early nineteenth century. The American Historical Review, 96(3), 763-794. Retrieved from http://www.jstor.org/stable/2162430

Boyle, M., \& Parry, K. (2007). Telling the whole story: the case for organizational autoethnography. Culture and Organization, 13(3), 185-90. http://dx.doi.org/ 10.1080/14759550701486480

Brade, I., \& Rudolph, R. (2004). Moscow, the global city? The position of the Russian capital within the European system of metropolitan areas. Area, 36(1), 69-80. http://dx.doi.org/10.1111/j.0004-0894.2004.00306.x

Brouwer, L. F. (2006). Teaching leadership in the Russian Federation: Looking through the post-Soviet lens. International Education Journal, 7(3), 333-347. Retrieved from http://ehlt.flinders.edu.au/education/iej/articles/v7n3/Brouwer/paper.pdf

Brown, K. (2010). The forsaken: the unfinished business of making plutonium in Russia. International Labor and Working-Class History, 78(1), 137-144. http://dx.doi.org/10.1017/S0147547910000219

Brue, S. L., \& MacPhee, C. R. (1995). From Marx to markets: Reform of the university economics curriculum in Russia. The Journal of Economic Education, 26(2), 182-195.

Cardon, P. W. (2008). A critique of Hall's contexting model: A meta-analysis of literature on intercultural business and technical communication. Journal of Business and Technical Communication, 22(4), 399-428. http://dx.doi.org/10.1177/1050651908320361

Chadraba, P. G., \& O'Keefe, R. D. (2007). Developing graduate marketing programs for economies in transition. Journal of Marketing Education, 29(3), 218-222. http://dx.doi.org/ 10.1177/0273475307306887

Chukhlomin, V. (1991, December 20). Budem uchit' chestnomu biznesu [We'll be teaching fair play in business]. Kommercheskie Vesti [A newspaper in Russian].

Chukhlomin, V. (2004a). Eksportnye strategii dlya rossiyskih vuzov [Export strategies for Russian institutions of higher learning]. Marketing $v$ Rossii i za rubezhom [Marketing in Russia and abroad], 4(38), 32-36.

Chukhlomin, V. (2004b). Kak podgotovit' spetsialista mirovogo klassa [How to prepare world class specialists]. EKO: Vserossiyskiy Ekonomicheskiy Zhurnal [ECO - All-Russia Economic Journal], 4, 159-177.

Chukhlomin, V. (2006). Rossiyskoye obrazovaniye s mezhdunarodnym komponentom [A Russian educational program with international component]. EKO: Vserossiyskiy Ekonomicheskiy Zhurnal [ECO - All-Russia Economic Journal], 4, 88-97.

Chukhlomin, V. (2007). Fakul'tet moei mechty [The school of my dream]. EKO: Vserossiyskiy Ekonomicheskiy Zhurnal [ECO - All-Russia Economic Journal], 4, 103-113. 
Chukhlomin, V. (2009). Kak podgotovit' spetsialista mirovogo klassa - statya vtoraya [How to prepare world class specialists - Revisited]. EKO: Vserossiyskiy Ekonomicheskiy Zhurnal [ECO - All-Russia Economic Journal], 6, 137-146.

Chukhlomin, V. (2010a). Delivering a SUNY degree in Siberia: What works and what doesn't from a host institution perspective. The Cross border education case studies repository. London, England: The Observatory on Borderless Higher Education.

Chukhlomin, V. (2010b). A laboratory of culture shock. All about Mentoring, 37, spring, 46-51.

Chukhlomin, V. (2011). O novyh obrazovatel'nyh standartah i mezhdunarodnyh sopostavleniyah [On new educational standards and international comparisons]. Vestnik S.-Petersburg University, 8(1), 137-155.

Chukhlomin, V., \& Deshpande, A. (2011). Developing bridging bilingual/bicultural (the 3B Framework) courses to prepare international students for the American online classroom in an adult learning environment. In Proceedings of Global Learn Asia Pacific 2011 (pp. 955-960). AACE (the Association for the Advancement of Computers in Education). Melbourne, Australia. Retrieved from http://www.editlib.org/p/37283

Chukhlomin, V., Chukhlomina, I., \& Thomas, M. (2012). How to outsource global skills development to Australian vocational colleges: A case study. In Proceedings of the IADIS conference. Perth, Australia (forthcoming).

Chukhlomina, I. (2002). Makroekonomicheskaya teoriya I ekonomika Rossii [The Macroeconomic Theory and the Russian Economy]. Omsk, Russia: Omsk State University Publishers.

Chukhlomina, I. (2003). Aktualnost' kontsepsii integrirovannogo marketinga dlya Rossiyskih predpriyatiy [Actuality of the integrated marketing concept for Russian enterprises]. Omsk, Russia: OmGU. ISBN 5-7779-0391-6: 110.00

Curtis, D. (2004). International perspectives on generic skills. In J. Gibb (Ed.), Generic skills. Canberra, Australia: Australian National Training Authority.

Czinkota, M. R. (1997). Russia's transition to a market economy: learning about business. Journal of International Marketing, 5(4), 73-93.

Denzin, N. (1997). Interpretive ethnography: Ethnographic practices for the 21st Century. Thousand Oaks, CA: Sage Publishers.

Doloriert, C., \& Sambrook, S. (2012). Organizational autoethnography. Journal of Organizational Ethnography, 1(1), 83-95. http://dx.doi.org/10.1108/20466741211220688

Dostoyevsky, Fyodor. (1965). Memoirs from the house of the dead. Oxford, England: Oxford University Press.

Egorshin, A. T., Abliazova, N. O., \& Gus'kova, I. V. (2007). Higher economic education in Russia, 1990-2025. Russian Education and Society, 49(10), 30-52. http://dx.doi.org/ 10.2753/RES1060-9393491002

Eklof, L. Holmes, \& V. Kaplan (Eds). (2005). Educational reform in post-Soviet Russia. London, England: Cass

Elenkov, D. (2002). Effects of leadership on organizational performance in Russian companies. Journal of Business Research, 55(6), 467-480. http://dx.doi.org/10.1016/SO148-2963(02)00488-5

Elliott, J., \& Tudge, J. (2007). The impact of the West on post-Soviet Russian education: Change and resistance to change. Comparative Education, 43(1), 93-112. Retrieved from http://www.jstor.org/stable/29727817

Ellis, C., \& Bochner, A. (2000). Autoethnography, personal narratives, reflexivity: Researcher as subject. In N. Denzin, and Y. Lincoln (Eds), Handbook of Qualitative Research (3rd ed) (pp. 1-32). London, England: Sage.

Erickson, G., S., Insinga, R., \& Kureshov, V. (2004). Business education in Russia: A Siberian perspective (pp. 299-309). In I. Alon \& J. R. McIntyre (Eds.). Business education and emerging market economies: perspective and best practices. Boston, MA: Kluwer Academic Publishing.

Evans, A. B. (2011). The failure of democratization in Russia: A comparative perspective. Journal of Eurasian Studies, 2(1), 40-51. http://dx.doi.org/10.1016/j.euras.2010.10.001

Global Alliance for Transnational Education (GATE). (1997). Certification manual. Washington, DC: GATE.

Gentile, M. (2004). Former closed cities and urbanization in the FSU: an exploration in Kazakhstan. Europe-Asia Studies, 56(2), 263-278. http://dx.doi.org/10.1080/0966813042000190533 
Gilbert, K. (2001). In search of Russian culture: the interplay of organizational, environmental and cultural factors in Russian-Western partnerships. Working papers series 2001, no. WP 003/01. Wolverhampton, England: Wolverhampton Business School Management Research Center.

Gilbert, K., \& Gorlenko, E. (1999). Transplant and process-oriented approaches to international management development: An evaluation of British-Russian co-operation. Human Resource Development International, 4(2), 335-354. http://dx.doi.org/10.1080/13678869900000037

Glaser, B. G., \& Strauss, A. L. (1967). The discovery of grounded theory: Strategies for qualitative research. Chicago, IL: Aldine Publishing Company.

Goldman, M. (2008). Petrostate: Putin, power, and the new Russia. New York and London: Oxford University Press.

Gronroos, C. (1999). Internationalization strategies for services. The Journal of Services Marketing, 13(4/5), 290-297. http://dx.doi.org/10.1108/08876049910282547

Harman, G. (2004). New directions in internationalizing higher education: Australia's development as an exporter of higher education services. Higher Education Policy, 17, 101-120. http://dx.doi.org/10.1057/palgrave.hep.8300044

Harris, R., Simons, M., \& McCarthy, C. (2006). Private training providers in Australia: Their characteristics and training activities, A National Vocational Education and Training Research and Evaluation Program report. Adelaide, Australia: National Centre for Vocational Education Research.

Hayano, D. M. (1979). Autoethnography: paradigms, problems and prospects. Human Organization, 38, $113-20$.

Haynes, K. (2011). Tensions in (re)presenting the self in reflexive autoethnographical research. Qualitative $\begin{array}{lllll}\text { Research in } \quad \text { Organizations } & \text { 134-49. }\end{array}$ http://dx.doi.org.library.esc.edu/10.1108/17465641111159125

Hedgepeth, O., \& Henrie, M. (2005). Exploring cultural implications of teaching logistics and project management in the Russian Far East. The Journal of Learning in Higher Education, 1(1), 31-35. Retrieved from http://jwpress.com/JLHE/Issues/JLHE-Fall2005-v1i1.pdf?Submit2=Fall+2005+Issue+\%28Copyright+2005 $+\mathrm{JW}+$ Press $\% 29+$

Hofstede, G. (1986). Cultural differences in teaching and learning. International Journal of intercultural Relations, 10(3), 301-320. http://dx.doi.org/10.1016/0147-1767(86)90015-5

Horta, H., Veloso, F. M., \& Grediaga, R. (2010). Navel-gazing: academic inbreeding and scientific productivity", Management Science, 56(3), 414-300. http://dx.doi.org/10.1287/mnsc.1090.1109

Jacobs, E. M. (2001). The influence of Western concepts on Russian marketing theory. The British Journal of Management, 12(2), 149-157. http://dx.doi.org/10.1111/1467-8551.00191

Jarvis, D., Kondrashova, M., Efendiev, A., \& Tukhvatullin, M. (2005). Faculty development in Russian higher education. International Journal for Academic Development, 10(2), 125-137. http://dx.doi.org/10.1080/13601440500281740

Judge, W., Miassoedov, S., \& Naoumova, I. (2004). The past, present and future state of Russian management education. International Journal of Business and Management Education, 12, 1-20. Retrieved from www.usq.edu.au/ /media/USQ/Business.../RussianMgtEdpdf.ashx

Kantorovich, L. V. (1965). The Best Uses of Economic Resources. Oxford, New York: Pergamon.

Karra, N., \& Phillips, N. (2008). Researching "Back Home": International management research as autoethnography. Organizational Research $\quad$ Methods, 11(3), http://dx.doi.org/10.1177/1094428106295496

Kempster, S., \& Stewart, J. (2010). Becoming a leader: A co-produced autoethnographic exploration of situated learning of leadership practice. Management Learning, 41(2), 205-219. http://dx.doi.org/10.1177/1350507609355496

Kets de Vries, M. E. R. (2001). The anarchist within: Clinical reflections on Russian character and leadership style. Human Relations, 54(5), 585-627. http://dx.doi.org/10.1177/0018726701545003

Khodarkovsky, M. (2002). Russian steppe frontier: The making of a colonial empire 1500-1800. Bloomington, IN: Indiana University Press. 
Kitaev, I. (1994). Russian education in transition: Transformation of labor market, attitudes of youth and changes in management of higher and lifelong education. Oxford Review of Education, 20(1), 111-130. http://dx.doi.org/10.1080/0305498940200107

Klein, S., \& Ward, M. (2003). An emerging market player in international business education: the case of Wits Business School. A working paper. Retrieved from http://www.ciber.gatech.edu/papers/workingpaper/2003/04-017.pdf

Knight, J. (2007). Higher education crossing borders: Programs and providers on the move (pp. 42-69). In D. Bruce Johnstone (Ed.). Higher education in a global society. Edward Elgar Publishing.

Lavigne, M. (1997). The political economy of socialism: what is left? Europa - Asia Studies, 49(3), 479-486. http://dx.doi.org/10.1080/09668139708412453

Leonard-Barton, D. (1990). A Dual methodology for case studies: Synergistic use of a longitudinal single site with replicated multiple sites. Organization Science, 1(3), 248-266.http://ds.doi.org/10.1287/orsc.1.3.248

Lincoln, W. B. (1994). The Conquest of a continent: Siberia and the Russians. New York, NY: Random House.

Lisauskene, M. (2006). A new generation of Russian college students. Russian Education and Society, 48(9), 6-17. http://dx.doi.org/10.2753/RES1060-9393480901

Malykhin, V., \& Chukhlomin, V. (1991). Doroga k rynku [A road to market economy]. Omsk, Russia: Omskoe knizhnoye izdatel'stvo.

McKenzie, L. W. (2002). Classical general equilibrium theory. Boston, MA: The MIT Press.

Meier, A. (2008, October 27). Score another one for Putin. New York Times. Retrieved from http://www.nytimes.com/2008/11/02/sports/playmagazine/112Russia.html?pagewanted=all\&_r=0

Melvin, N. J. (1998). The consolidation of new regional elite: the case of Omsk, 1987-1995. Europa - Asia Studies, 50(4), 619-650. http://dx.doi.org/10.1080/09668139808412557

Mikheyev, D. (1987). The Soviet mentality. Political Psychology, 8(4), 491-523.

Miles, H., \& Huberman, M. (1994). Qualitative data analysis: A sourcebook. Beverly Hills, CA: Sage Publications,

Moiseeva, M. (2005). Distance education in Russia: Between the past and the future. The Quarterly Review of Distance Education, 6(3), 217-225. Retrieved from http://www.infoagepub.com/index.php?id=89\&i=13

Naumov, I. V. (2006). The History of Siberia, ed. by David N. Collins. Routledge: London and New York.

Naumova, T. V. (1998). Russia's "Brain Drain". Russian Social Science Review, 39(2), 49-56. http://dx.doi.org/10.2753/RSS1061-1428390249

Parry, K., \& Boyle, M. (2009). Organizational autoethnography. In D. Buchanan and A. Bryman (Eds.). The Sage handbook of organizational research methods (pp 690-702). London, England: Sage Publishers.

Pendergast, W. (2009). Challenges and opportunities of business education in Southeast Europe: The case of Balkan Business School. Journal of Teaching in International Business, 20, 244-267. http://dx.doi.org/10.1080/08975930903099242

Pimpa, N. (2003). The influence of family on Thai students' choices of international education. The International Journal of Educational Management, 17(5), 211-219. http://dx.doi.org/10.1108/09513540310484931

Postanovleniye Glavy Administratsii - Gubernatora Omskoi Oblasti. (1998). 'O podderzhke Rossiysko-Amerikanskogo Proekta s Uchastiem Omskogo Gosudarstvennogo Universiteta [The Head of Administration (Governor) of the Omsk Oblast's decree 'On support of the Russian-American Project with participation of the Omsk State University in the sphere of economic education]. Retrieved June 23, 2011, from http:// www.lawru.info/base94/part3/d94ru3209.htm

Prokopenko, I. A., \& Baksheeva, L. M. (2008). College students' need for the distance model of education. Russian Education and Society, 50(3), 35-44. http://dx.doi.org/10.2753/RES1060-9393500303

Puffer, S. M. (1993). The booming business of management education in Russia. Journal of Management Development, 12(5), 46-59. http://dx.doi.org/10.1108/02621719310038962

Puffer, S. M., \& McCarthy, D. J. (2011). Two decades of Russian business and management research: An institutional theory perspective. Academy of Management Perspectives, 25(2), 21-36. http://dx.doi.org/10.5465/AMP.2011.61020800 
Remnev, A. (2003). Siberia and the Far East in the Russian Empire (19th century - early 20th century). Omsk: Omsk State University. Retrieved from http://web.ceu.hu/crc/cdc/syllabi/Remnev1.doc.

Riordan, J. (2007). Football: nation, city and the dream: playing the game for Russia, money and power. Soccer \& Society, 8(4), November, 545-560. http://dx.doi.org/10.1080/14660970701440840

Ross, J. (2011, June 20). Fewer passengers from India? The Australian. Retrieved from http://www.theaustralian.com.au/higher-education/opinion/fewer-passengers-from-india/story-e6frgcko-122 6078552676

Sachau, D., Brasher, N., \& Fee, S. (2010). Three models for short-term study abroad. Journal of Management Education, 34(5), 645-670. http://dx.doi.org/ 10.1177/1052562909340880

Schellenberger, R. E. (1996). Comparison of CIS curricula in Russian and American universities. Project Innovation, winter, 1-7.

Shabanova, M. A. (2010). Business education in Russia: Characteristics of the new generation of business people. Russian Education and Society, 52(4), 36-62. http://dx.doi.org/10.2753/RES1060-9393520403

Sharygin, I. (2002). Mathematical education and society (an outlook from Russia and into Russia). The Teaching of Mathematics, 5(2), 71-80. Retrieved from http://elib.mi.sanu.ac.rs/files/journals/tm/9/tm522.pdf

Shaw M., \& Ormson, M. (2001). Values and vodka: Cross-cultural anatomy of an Anglo-Russian educational project. International Journal of Educational Development, 21(2), 119-133. http://dx.doi.org/10.1016/S0738-0593(00)00023-7

Shaw, S. O., Burakova, N., \& Makoukha, V. (2000). Economic education in Russia: A case study. S.A.M. Advanced Management Journal, 65(3), 29-34. Retrieved from http://www.questia.com/read/1G1-64912373/economic-education-in-russia-a-case-study

Shelley, L. I. (1995). Privatization and crime: The post-Soviet experience. Journal of Contemporary Criminal Justice, 11(4), 244-256. http://dx.doi.org/10.1177/104398629501100405

Smolentseva, A. (2003). Challenges to the Russian academic profession. Higher Education, 45(4), 391- 424.

Snell, D., \& Hart, A. (2007). Vocational training in Australia: Is there a link between attrition and quality? Education + Training, 49(6), 500 - 512. http://dx/doi.org/ 10.1108/00400910710819145

Sohail, M.S., Daud, S., \& Rajadurai, J. (2006). Restructuring a higher education institution; a case study from a developing country. International Journal of Educational management, 20(4), 279-290. http://dx.doi.org/10.1108/09513540610665397

Stevens, B. (2000). Russian teaching contracts: An examination of cultural influence and genre. Journal of Business and Technical Communication, 14(1). http://dx.doi.org/38-58.10.1177/105065190001400102

Unterberger, B. M. (1957). The Russian revolution and Wilson's Far-Eastern policy. The Russian Review, 16(2), $35-46$. Retrieved http://links.jstor.org/sici?sici=0036-0341\%28195704\%2916\%3A2\%3C35\%3ATRRAWF\%3E2.0.CO\%3B2 $-8$

Van Maanen, J. (1988). Tales of the filed: On writing ethnography. Chicago, IL: Chicago University Press.

Van`t Klooster, E., Van Wijk, J., Go, F., \& Van Rekom, J. (2008). Educational travel. Annals of Tourism Research, 35(3), 690-711. http://dx.doi.org/10.1016/j.annals.2008.05.003

Varner, I., \& Varner, C. (1994). A culture-based framework for successful business training in Russia. Human Resources Development Quarterly, 5(4), 361-369. http://dx.doi.org/10.1002/hrdq.3920050407

Voss, C., Tsikriktsis, N., \& Frohlich, M. (2002). Case research in operations management. International Journal of Operations \& Production Management, 22(2), 195-219. http://dx.doi.org/10.1108/01443570210414329

Yang, R. (2005). Internationalizing Chinese higher education: A case study of a major comprehensive university. In P. Ninnes and M. Hellstein (Eds). Internationalizing higher education. Springer, 97-118.

Yin, R. (1984). Case study research: Applied social research methods series, 5. Beverley Hills, CA: Sage Publications.

Zajda, J. (2007). Reforms in higher education in the Russian Federation: Implications for Equity and social justice. European Education, 39(2), 20-36. http://dx.doi.org/10.2753/EUE1056-4934390201

Zaslavskaya, T. I. (1984). The Novosibirsk report. Survey, 28(1), 83-109. 